\title{
Asymmetry in Voltage-Dependent Movements of Isolated Outer Hair Cells from the Organ of Corti
}

\author{
J. Santos-Sacchi \\ Laboratory of Otolaryngology, UMDNJ-New Jersey Medical School, Newark, New Jersey 07103
}

\begin{abstract}
The electrically induced movements of outer hair cells (OHC) were studied using the whole-cell voltage-clamp technique and video analysis. Cell shortening occurs during depolarization and elongation occurs during hyperpolarization from holding potentials near $-70 \mathrm{mV}$. However, a marked asymmetry in response magnitude exists such that depolarization produces larger cell length changes than do comparable levels of hyperpolarization. The response is such that at normal resting potentials in vivo, displacements are about $2 \mathrm{~nm} / \mathrm{mV}$, but increase to about $15 \mathrm{~nm} / \mathrm{mV}$ as the cell is depolarized. This mechanical rectification in the depolarizing direction manifests itself during symmetrical sinusoidal voltage stimulation as a "DC" reduction in cell length superimposed upon "AC" length changes. The observed OHC mechanical rectification may be involved in the reported production of "DC" basilar membrane displacements during suprathreshold acoustic stimulation (LePage, 1987). Estimates of the magnitude of $\mathrm{OHC}$ movements at acoustic threshold levels induced by receptor potentials in the highfrequency region of the cochlea indicate a disparity between basilar membrane and $\mathrm{OHC}$ movements on the order of 21 dB. Thus, it appears questionable whether OHC mechanical movements solely underlie the "active process" thought to be responsible for the hlgh degree of neural tuning at sound pressures near $0 \mathrm{~dB}$.
\end{abstract}

The organ of Corti is composed of a variety of cell types, including supporting and receptor cells. Two populations of receptor cells exist in the organ, inner (IHC) and outer hair cells $(\mathrm{OHC})$. Each type of hair cell produces receptor potentials in response to acoustic stimulation (Dallos et al., 1982; Russell and Sellick, 1983). However, IHCs receive the majority of afferent innervation from the eighth nerve (Spoendlin, 1969), indicating the IHC's predominant role in information transfer to the CNS. It is becoming increasingly clear that OHCs influence, possibly through mechanical means, the electrical activity of IHCs (Mountain, 1980; Siegal and Kim, 1982; Brown et al., 1983; Nuttall, 1985). The net result of this interaction is the exquisite tuning characteristics and sensitivity of eighth nerve fibers.

Direct electrical stimulation of isolated $\mathrm{OHCs}$ induces reversible cell length changes on the order of micrometers which

Received Sept. 29, 1988; revised Jan. 13, 1989; accepted Jan. 30, 1989.

Supported by an NINCDS Research Career Development Award and NIH gran

NS21380. I thank C. Witzmann and J. Nolan for technical assistance, and Jon

Allen and Bill Brownell for many helpful discussions.

Correspondence should be addressed to J. Santos-Sacchi, Laboratory of Oto-

laryngology, UMDNJ-New Jersey Medical School, MSB H518, 185 S. Orange

Ave., Newark, New Jersey 07103.

Copyright (C) 1989 Society for Neuroscience $0270-6474 / 89 / 082954-09 \$ 02.00 / 0$ are not based upon an actin-myosin system (Brownell et al., 1985; Ashmore, 1986; Brownell, 1986; Kachar et al., 1986). These fast mechanical responses, measured up to $8 \mathrm{kHz}$ (Ashmore and Brownell, 1986; Ashmore, 1987), conceivably underlie the mechanical interactions alluded to above and appear to depend upon transmembrane potential since blocking the known ionic conductances of these cells during voltage clamp does not interfere with the mechanical response due to depolarization (Santos-Sacchi and Dilger, 1988a, b). Thus, the OHC may function as both receptor and effector, generating receptor potentials that modify cell length and, in turn, influence organ of Corti micromechanics.

Brownell $(1983,1984)$ first demonstrated the polarity dependence of electrically induced $\mathrm{OHC}$ movements-hyperpolarizing currents elongate and depolarizing currents shorten the $\mathrm{OHC}$. Studies on the displacement magnitude due to electrical stimulation in the hyperpolarizing and depolarizing directions have provided conflicting results. Ashmore (1987) determined that the responses are largely symmetrical, whereas Evans (1988) found them to be asymmetrical. The asymmetry noted by Evans indicates that for a given stimulus magnitude, elongation of the $\mathrm{OHC}$ is as much as $50 \%$ greater than shortening. Considering the recent finding of LePage (1987) that basilar membrane "DC" displacements occur in response to tone bursts and that $\mathrm{OHC}$ movements may be implicated, it is important to determine the existence and extent of mechanical rectification in the OHC.

Preliminary reports of some of the results have been presented (Santos-Sacchi, 1988a, b).

\section{Materials and Methods}

Sensory and supporting cells were isolated from guinea pig cochleas by gentle pipetting of the isolated top 2 turns of the organ of Corti. No enzymatic digestion was employed for hair cell isolation. The cell-enriched supernatant was then transferred to a $700 \mu$ l perfusion chamber, and cells were permitted to settle onto the coverglass bottom. A Nikon Diaphot inverted microscope with Hoffmann optics was used to observe the cells during electrical recording. A modified Leibovitz medium $(\mathrm{NaCl}$, $142.2 \mathrm{~mm} ; \mathrm{KCl}, 5.37 \mathrm{~mm} ; \mathrm{CaCl}_{2}, 1.25 \mathrm{~mm} ; \mathrm{MgCl}_{2}, 1.48 \mathrm{~mm}$; HEPES, $5.0 \mathrm{~mm}$; dextrose, $5.0 \mathrm{~mm}$; pII 7.0-7.2) was used as the perfusate. Patch electrodes (flint glass) had initial resistances of 3-5 M 2 . The series resistance, i.e., the actual electrode resistance obtained upon establishment of whole-cell configuration, typically ranged from 8 to $15 \mathrm{M} \Omega$. These values were estimated from current transients initiated at the onset of voltage pulses and were corrected during analysis (Marty and Neher, 1983). Pipette solutions were composed of $140 \mathrm{~mm} \mathrm{KCl}, 1,5$, or $10 \mathrm{mM}$ EGTA, $2 \mathrm{mM} \mathrm{MgCl}_{2}$, and $5 \mathrm{mM}$ HEPES buffered to $\mathrm{pH} 7.0-$ 7.2. Giga-ohm seals were obtained at the nuclear level of the $\mathrm{OHC}$ membrane prior to whole-cell recording.

Single cells were clamped to holding potentials near $-70 \mathrm{mV}$ using a Dagan patch-clamp amplifier. Under computer control, hyperpolarizing and depolarizing voltage steps, $200 \mathrm{msec}$ long, nominally ranging from -170 to +30 or $+50 \mathrm{mV}$, in 10 or $20 \mathrm{mV}$ steps, were used to elicit membrane currents and mechanical movements. Current records, filtered at $2 \mathrm{kHz}$ with an 8-pole Bessel filter, were digitized and stored 
on a Data 6000 waveform analyzer and saved to disk for off-line analysis. All OHC movements were taped with a Panasonic AG6300 video recorder. Movements of the cuticular plate region were analyzed off the video monitor during playback using differential optoresistors (output filtered at $30 \mathrm{~Hz}$ ) placed across the image of the cuticular plate at a monitor magnification of $2800 \times$. The linearity of the optoresistor method was confirmed by measuring the video taped movement of the tip of a microelectrode driven by a piezoelectric bimorph element (Fig. 2C). Absolute values were determined by measuring off the video monitor the cell movement in response to the largest depolarizing voltage step. The error in absolute measures was estimated to be less than $20 \%$. Apical and basal ends of the $\mathrm{OHC}$ move towards and away from the electrode insertion point during depolarization and hyperpolarization, respectively (Santos-Sacchi and Dilger, 1988a, b). Because the movement of the cuticular plate is relative to the stationary insertion point of the electrode, which was typically near the nuclear region, total cell length change was determined by multiplying the measured movements of the cuticular region by the ratio of total cell length to electrode-cuticular plate distance.

OHC capacitance measures were determined by 2 methods. Electrode shanks were coated with M-coat D (M-Line Accessories, Raleigh, NC) in order to reduce electrode capacitance, and during gigaseal establishment and prior to cell entry, electrode capacitance was compensated fully. For these procedures the current records were filtered at 7 or 10 $\mathrm{kHz}$. The first method involved a determination of the time constant of the initial current transient of the whole-cell voltage-clamp circuit in response to a vollage step of $10 \mathrm{mV}$ from the holding potential. The time constant was estimated by a computerized exponential fitting procedure. The electrode series resistance was estimated from the fitted onset current, and the cell resistance, corrected for the series resistance, was measured from the steady-state current. The capacitance and time constant of the cell were determined as follows (Lecar and Smith, 1985; Ogden and Stanfield, 1987):

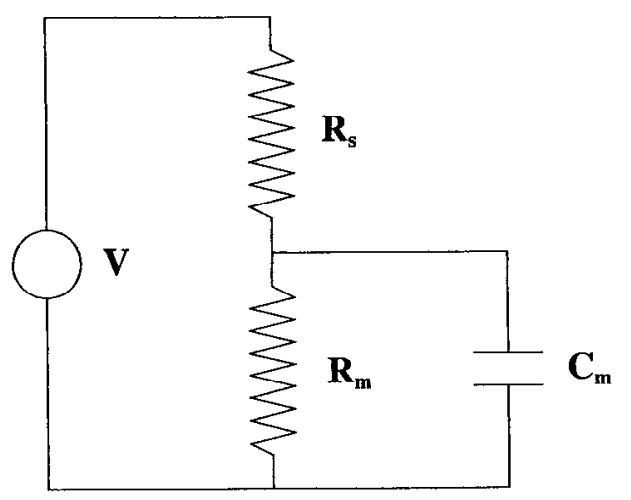

Clamp - cell model

$$
\begin{aligned}
\tau_{\text {clamp }} & =C_{m} R_{\|}, \text {where } R_{\|}=\left[\frac{R_{m} R_{s}}{R_{m}+R_{s}}\right] \\
C_{m} & =\frac{\tau_{\text {clamp }}}{R_{\|}} \\
\tau_{\text {cell }} & =R_{m} C_{m}
\end{aligned}
$$

where $\tau_{\text {clamp }}$ is the voltage-clamp time constant, $C_{m}$ is the capacitance of the cell, $R_{m}$ is the resistance of the cell, $R_{s}$ is the series resistance of the electrode, $R_{\|}$is the parallel resistance of $R_{t r}$ and $R_{s}$, and $\tau_{\text {cell }}$ is the time constant of the cell.

The other method involved an AC analysis of the whole-cell voltageclamp circuit, using a DSP-16 digital signal-processing unit with associated software (sYsiD; Ariel Corp., NY). After establishing whole-cell configuration, periodic swept frequency bursts $(0.005-8 \mathrm{kHz})$ of a constant voltage (5-20 mV peak) were delivered through the electrode at a holding potential near $-70 \mathrm{mV}$. The frequency response of the clamp amplifier was $10 \mathrm{kHz}$. Current responses were time-averaged a minimum of 20 times. The resultant average was fast-Fourier-transformed and stored for subsequent analysis. An analysis of the current magnitude responses provides the necessary information for cell-capacitance determination.
The input impedance of the whole-cell voltage-clamp model is given as follows (Lakshminarayanaiah, 1984), where $s=j \omega, \omega=2 \pi \mathrm{f}$, and $j=$ $\sqrt{-1}$ :

$$
Z_{\text {in }}=\left(R_{s}+R_{i n}\right)\left[\frac{1+R_{\|} C_{m} s}{1+R_{m} C_{m} s}\right]
$$

Substituting the time constant terms $\tau_{\mathbb{1}}$ for $R_{\mathrm{l}} C_{m}$, and $\tau_{m}$ for $R_{m} C_{m}$,

$$
Z_{\text {in }}=\left(R_{s}+R_{m}\right)\left[\frac{1+\tau_{\Perp} s}{1+\tau_{m} s}\right] .
$$

The resulting magnitude function for $I=V / Z_{\text {in }}$ is a high-pass response (sce Fig. $6 B$ ) with a high-frequency asymptote whose magnitude is dependent upon $R_{s}$ and whose $3 \mathrm{~dB}$ break frequency $\left(f_{\text {high }}\right)$ is related to $\tau_{\|}$. The low-frequency asymptote is dependent upon $R_{s}+R_{m}$, and its break frequency is related to $\tau_{m}$. Thus, the capacitance can be calculated by

$$
C_{m}=\frac{1}{2 \pi R_{\mid} f_{\text {high }}} .
$$

\section{Results}

A variety of cell types can be viably isolated from the mammalian organ of Corti. These include outer and inner hair cells, Deiter cells, and Hensen cells. Although OHCs and Deiter cells are easily isolated mechanically without the use of enzymatic treatment, Hensen cells require additional trypsinization to obtain single cells. IHCs are seen in short rows of cells.

Figure 1 illustrates $I-V$ plots of these cell types with their associatcd current traces. All cells demonstrate an outward rectification upon depolarization from a holding potential near -70 $\mathrm{mV}$. In Hensen cells and OHCs these outward currents have been shown to be $\mathrm{K}^{+}$currents (Santos-Sacchi and Dilger, 1986, 1988a, b; Santos-Sacchi, 1988a, b). The magnitude and voltage dependence of outward rectification varies among cell type, with the IHC demonstrating the largest currents. The time dependence of outward currents also differs, although OHCs and Deiter cells are similar. Despite some electrical similarities among these cells, only $\mathrm{OHCs}$ respond to voltage steps from the holding potential by altering their cell length (Fig. 2). The length changes are not dependent upon specific or total transmembrane current but appear to be voltage dependent (Santos-Sacchi and Dilger, $1988 \mathrm{a}, \mathrm{b})$.

The direction of the $\mathrm{OHC}$ length changes depends upon the polarity of the step; however, the magnitude of length change is not equal for symmetrical voltage displacements of opposite polarity. Depolarizations elicit larger mechanical responses than do hyperpolarizations. Figure $2, A, B$ illustrates whole-cell currents and mechanical responses for an isolated $\mathrm{OHC}$ in response to voltage steps above and below the holding potential of -67 $\mathrm{mV}$. Time- and voltage-dependent outward currents are generated in response to depolarization; inward currents generated upon hyperpolarization probably represent currents of the anomalous inward rectifier, as described by Ohmori (1984) in vestibular hair cells. The voltage-dependent displacements of the $\mathrm{OHC}$ are linear with voltage steps in the depolarizing direction (up to $+20 \mathrm{mV}$, above which the response begins to saturate; Santos-Sacchi and Dilger, 1988a, b). However, mechanical responses saturate rapidly at step levels more negative than the holding potential. This phenomenon is demonstrated for 9 cells in Figure 3. In each case, the mechanical response is rectified in the depolarizing direction. The average response in the depolarizing direction is about $15 \mathrm{~nm} / \mathrm{mV}$; in the hyper- 


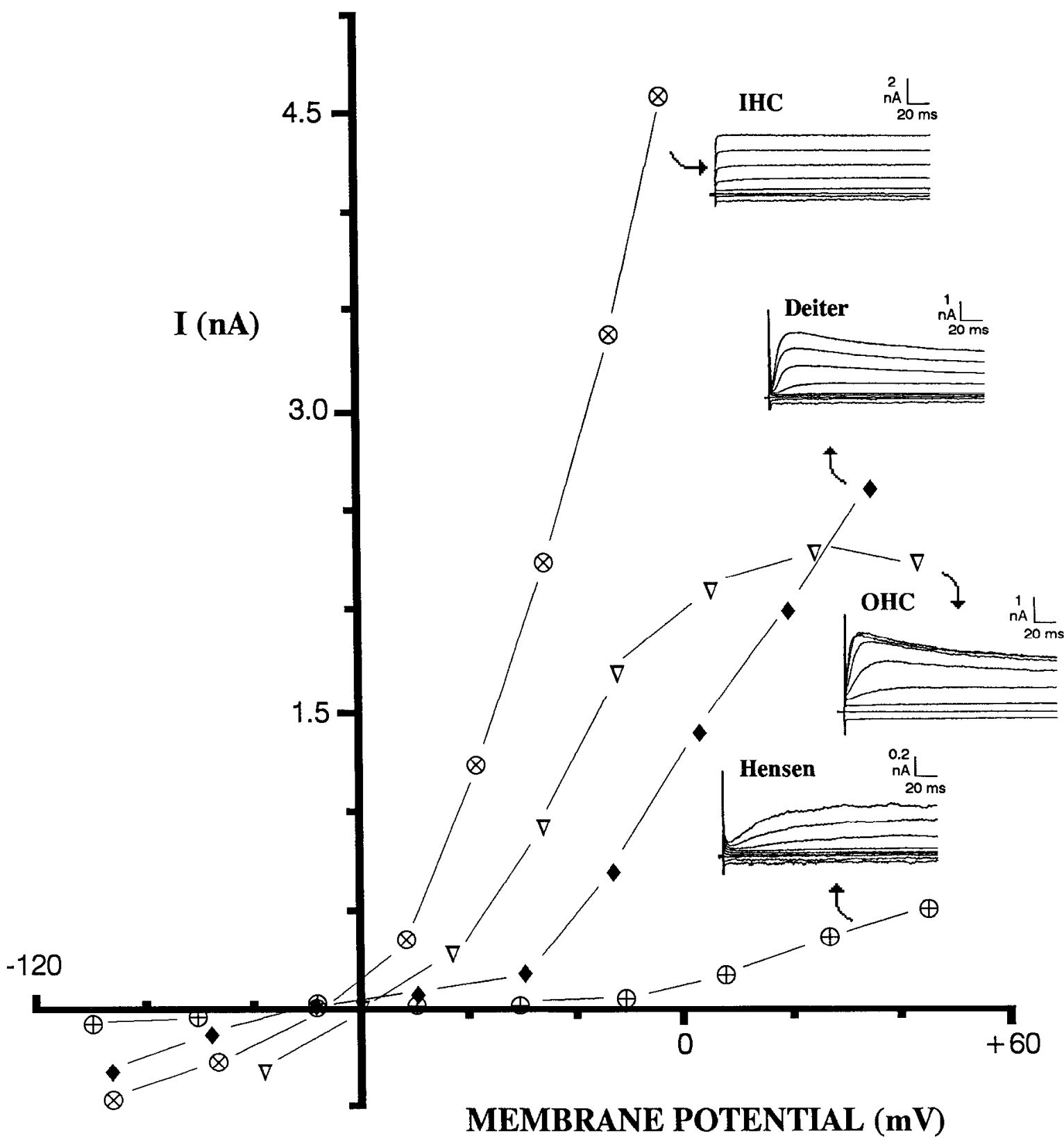

Figure 1. Examples of current recordings from isolated cells from the organ of Corti under whole-cell voltage clamp. Electrode solution contained $140 \mathrm{~mm} \mathrm{~K} \mathrm{~m}^{+}, 2 \mathrm{~mm} \mathrm{MgCl}_{2}, 1 \mathrm{~mm}$ EGTA, $5 \mathrm{~mm}$ HEPES, pH 7.0. Traces and plots are not leakage-subtracted. Note differences in current-magnitude scales beside each trace. Holding potentials and input resistances corrected for series resistance: Hensen cell, $-69.6 \mathrm{mV}, 687 \mathrm{M} \Omega$; Deiter cell, -68.3 $\mathrm{mV}, 127 \mathrm{M} \Omega$; OHC, $-59.7 \mathrm{mV}, 69 \mathrm{M} \Omega ; \mathrm{IHC},-67.4 \mathrm{mV}, 92 \mathrm{M} \Omega$.

polarizing direction, it is about $2 \mathrm{~nm} / \mathrm{mV}$. It was of interest to determine whether the rectified mechanical response is dependent upon rectified currents generated during voltage steps (Santos-Sacchi and Dilger, 1988a, b). Treatments that block the various ionic conductances of OHCs (e.g., intracellular $\mathrm{Cs}^{+}$, extracellular $\mathrm{Cd}^{2+}, \mathrm{Ba}^{2+}$, TEA) also do not affect the mechanical rectification. Figure 4 demonstrates the $\mathrm{Ca}^{2+}$ independence of the mechanical rectification. In this case, the electrode solution contained 5 mM EGTA and no added calcium, and the extracellular medium contained 1 mM EGTA with no added calcium.

This mechanical rectification indicates that sinusoidal voltage stimulation should produce a sustained shortening of the $\mathrm{OHC}$ during an $\mathrm{AC}$ voltage stimulus. This, in fact, occurs. Figure $5 \mathrm{~A}$ demonstrates the mechanical rectification of an $\mathrm{OHC}$ in response to $400 \mathrm{msec}$ bursts of a $10 \mathrm{~Hz}$ command voltage of about $90 \mathrm{mV}$ peak to peak, at a holding potential near $-70 \mathrm{mV}$. The " $A C$ " mechanical response is superimposed upon a " $D C$ " shift (reduction) in the length of the cell. The trace in Figure $5 B$ is the response of a glass probe driven at $10 \mathrm{~Hz}$ by a piezoelectric bimorph, which displays symmetrical movements, indicating that rectification under these conditions is not due to the measuring technique. Higher frequency stimulation of $\mathrm{OHCs}$ also produced a "DC" shift, but the " $A C$ " response appeared as a blurring of the image on the video monitor. Because the linear portion of the $\mathrm{OHC}$ mechanical response function lies roughly between -60 and $+20 \mathrm{mV}$, the value of the holding potential 


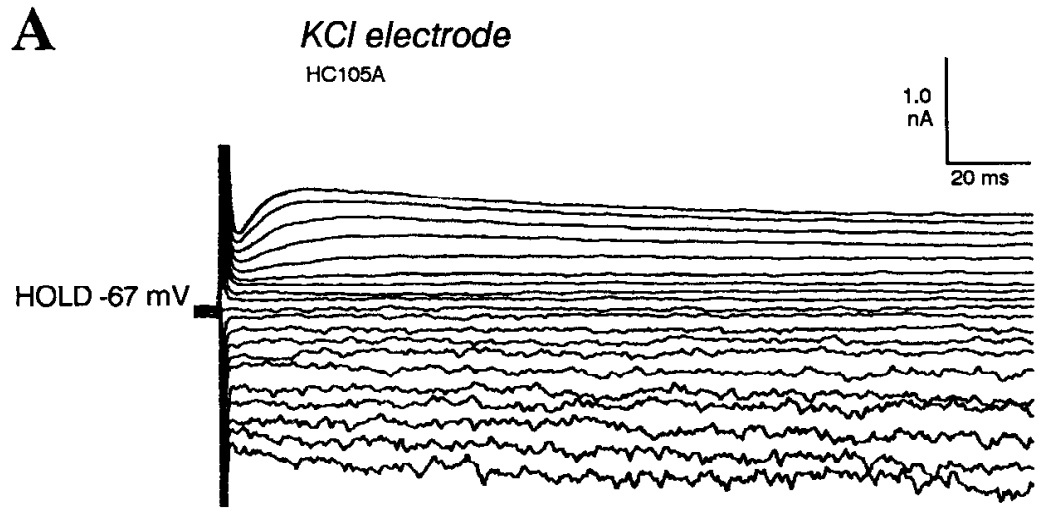

B

\section{MEMBRANE POTENTIAL (mV)}

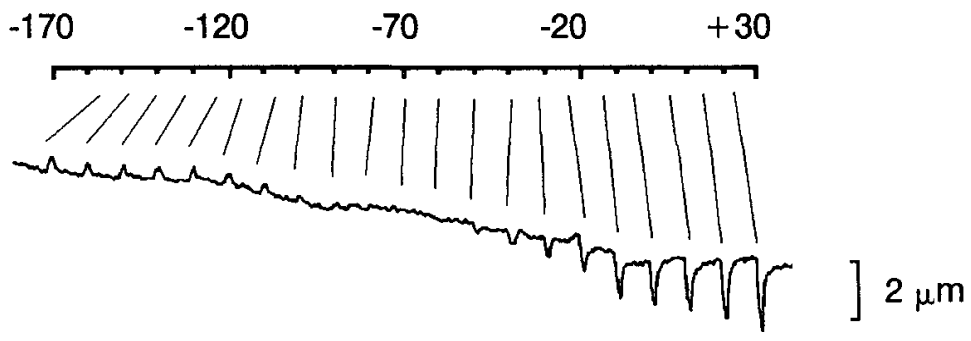

C
Figure 2. $A$, An isolated $\mathrm{OHC}$ was whole-cell voltage-clamped at a holding potential of $-67 \mathrm{mV}$ and stepped to various membrane potentials for periods of $200 \mathrm{msec}$. The traces depict currents generated during depolarizations (upward) and during hyperpolarizations (downward). The membrane potentials during each step are illustrated in $B . B$, Record of the output from the differential optoresistor indicating the magnitude of the cell's displacement (downward deflections represent cell shortening). The lines point to the membrane potential of the cell, corrected for series resistance, during each displacement. Note that cell elongations associated with hyperpolarizing voltage steps saturate rapidly above the holding potential, whereas cell contractions associated with depolarizations do not saturate in the range of voltages studied here. $C$, A glass probe driven by a piezoelectric bimorph was displaced for $200 \mathrm{msec}$ and then returned to baseline. Twenty displacements, in linearly graded steps, were produced such that an absolute maximum displacement of about $\pm 2 \mu \mathrm{m}$ about the resting baseline was video recorded. The displacements were measured during playback with differential optoresistors placed on the video screen over the image of probe, perpendicular to the displacement axis. The linearity of the measuring device is evident in the recorded output. should influence the direction of mechanical rectification due to sinusoidal stimulation. Figure $5 C$ illustrates this effect. When the holding potential is changed from -70 to $0 \mathrm{mV}$, the direction of the "DC"' length shift appears to reverse. This occurs because the hyperpolarizing phase of the stimulus now resides in the linear portion of the mechanical response function, whereas at a holding potential of $-70 \mathrm{mV}$ the depolarizing phase of the stimulus resided in the linear portion of the function.

Capacitance of the $\mathrm{OHC}$ was estimated for a total of 15 cells using 2 methods described in Materials and Methods. Figure 6 illustrates examples for each method. The current transient method $(n=8)$ yielded an average $( \pm \mathrm{SD})$ capacitance of 38.6 $\pm 4.7 \mathrm{pF}$, with an average clamp time constant $\left(\tau_{\text {clamp }}\right)$ equal to $0.34 \pm 0.072 \mathrm{msec}$ and an average cell resistance equal to 96 $\pm 91 \mathrm{M} \Omega$. The $\mathrm{AC}$ analysis method $(n=7)$ yielded a capacitance of $39.5 \pm 5.7 \mathrm{pF}$, with an average $\tau_{\text {clamp }}$ equal to $0.38 \pm 0.15$ msec and an average cell resistance equal to $80 \pm 34 \mathrm{M} \Omega$. These mcasurcments indicatc an average OHC membrane time constant of about $3.5 \mathrm{msec}$.
The average cell surface area of these cells, using a cylindrical cell body model and not including stcrcocilia, was $2.32 \pm 0.45$ $\times 10^{-5} \mathrm{~cm}^{2}$ for the transient analysis group and $2.50 \pm 0.38 \times$ $10^{-5} \mathrm{~cm}^{2}$ for the $\mathrm{AC}$ analysis group. Stereocilia measures were not included because most cells lose their stereocilia during the isolation procedure. If actual basolateral surface area is $133 \%$ of that estimated from light microscopy (due to lateral membrane ruffling; Dallos, 1983), then the specific capacitance of the OHC membrane is roughly $1.2 \mu \mathrm{F} / \mathrm{cm}^{2}$.

\section{Discussion}

Of all the cells studied that rest upon the basilar membrane, only the OHCs appear to respond to voltage alterations by modifying their cell length. These cells are truly unique in that they may function as both receptor and effector. The mechanical responses of $\mathrm{OHCs}$ are large in the depolarizing direction, attaining length reductions up to a few micrometers; however, the responses are rectified such that at typical in vivo resting potentials of -70 to $-90 \mathrm{mV}$, responses are much smaller. Thus, at 

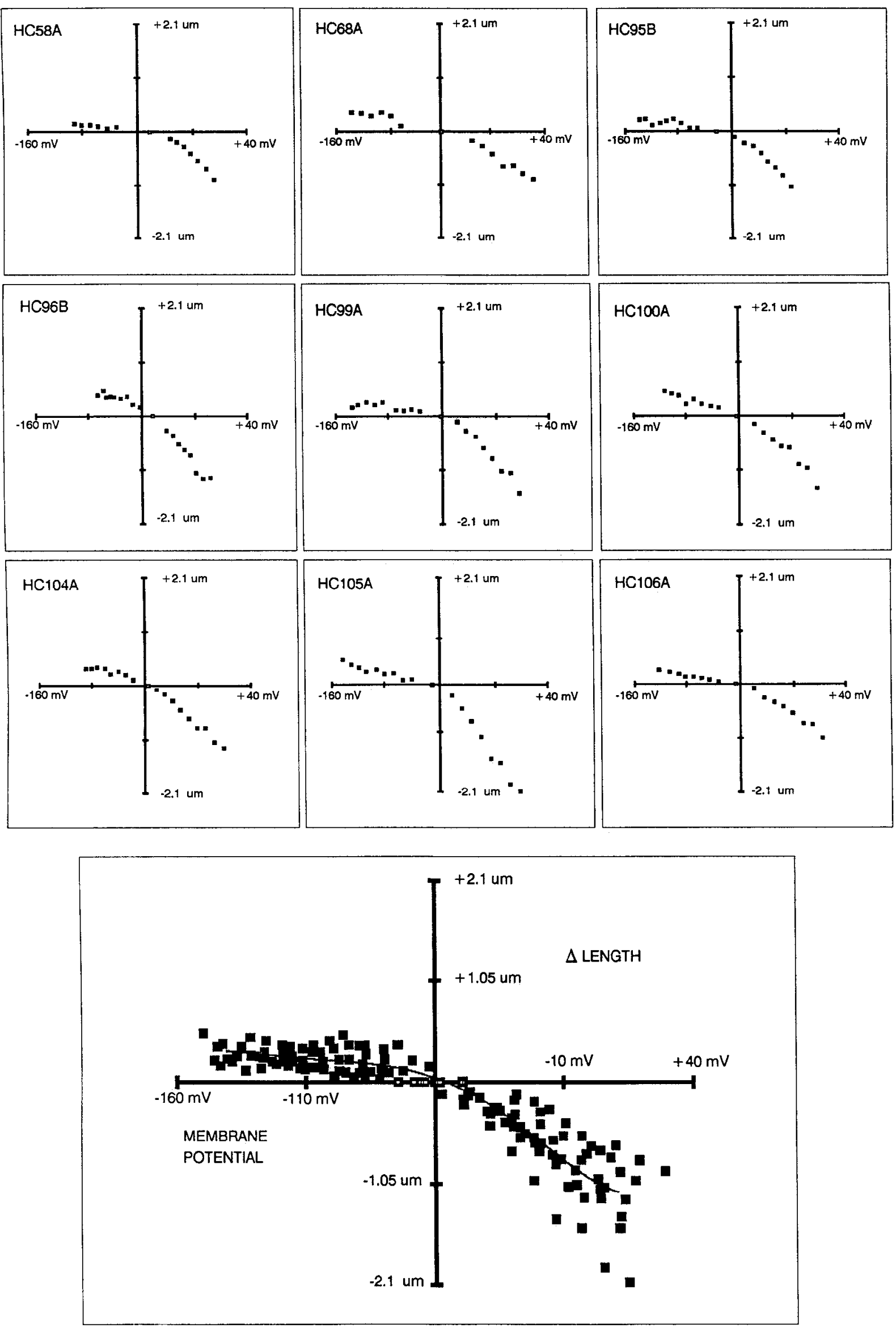

Figure 3. Voltage-displacement functions for $9 \mathrm{OHCs}$. Open boxes on the absciss $a$ indicate the holding potential. Each function was measured as in Figure 2. In each case, mechanical responses to depolarizations are larger than equivalent amplitude hyperpolarizations. Pooled data in the bottom plot clearly indicate the mechanical rectification in the depolarizing direction. The average slope in the depolarizing direction is about 15 $\mathrm{nm} / \mathrm{mV}$, and in the hyperpolarizing direction $<2 \mathrm{~nm} / \mathrm{mV}$. 


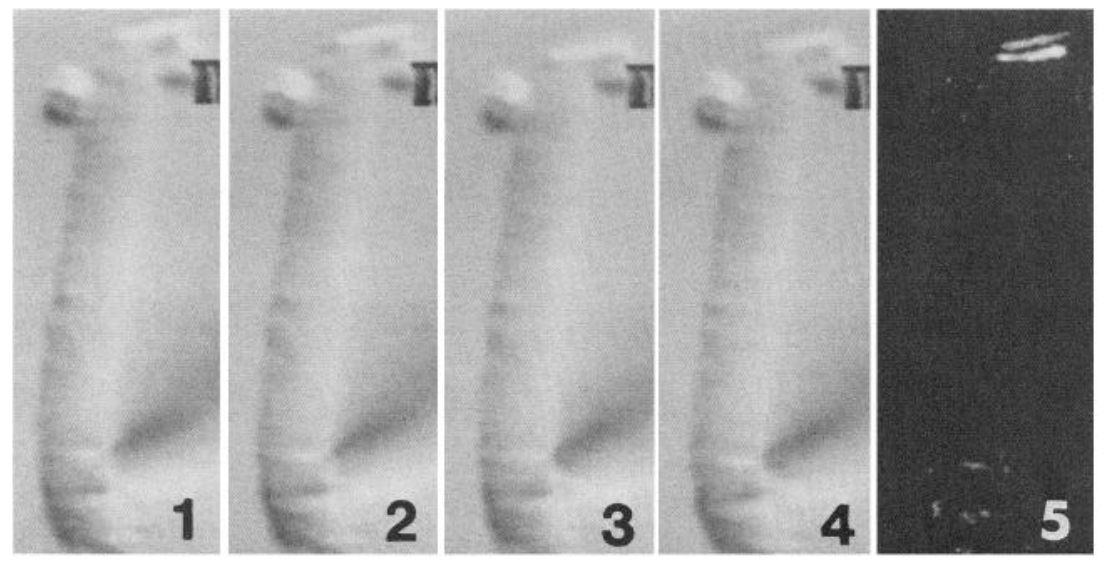

B

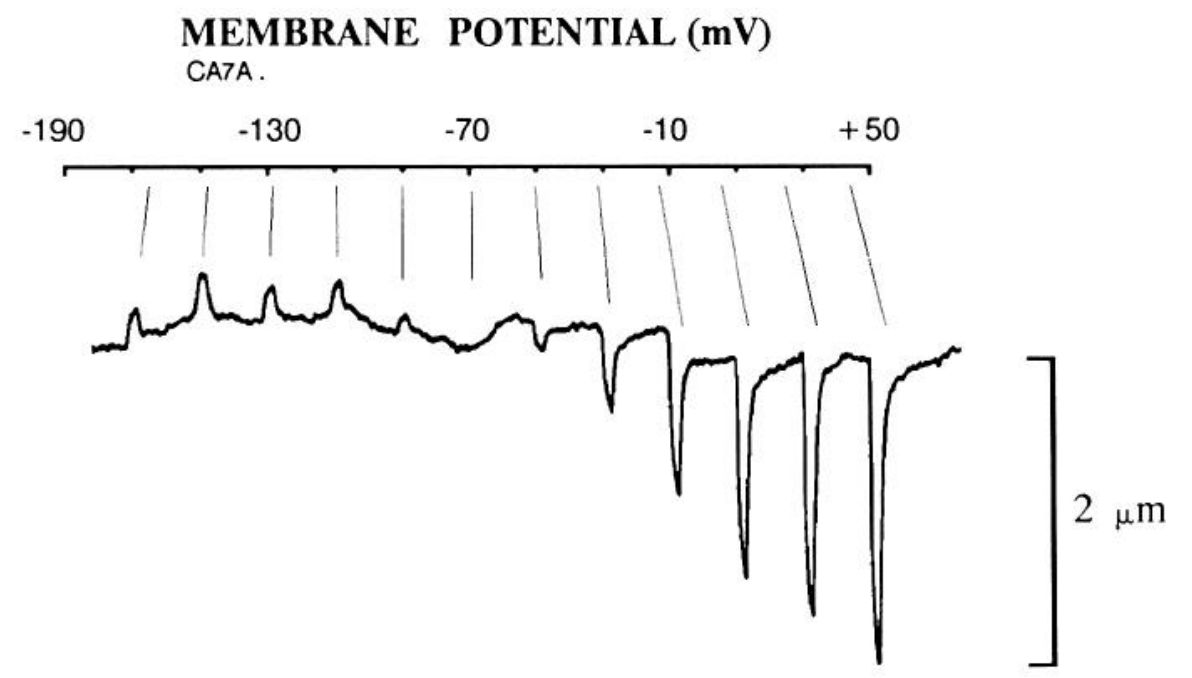

MEMBRANE POTENTIAL (mV) A7A.

Figure 4. Rectification of $\mathrm{OHC}$ mechanical response in $\mathrm{Ca}^{2}$-free, $1 \mathrm{~mm}$ EGTA extracellular media. Electrode solution contained $140 \mathrm{~mm} \mathrm{KCl}, 2 \mathrm{~mm}$ $\mathrm{MgCl}_{2}, 5$ тм EGTA, 5 mм HEPES, pH $7.0 \mathrm{~A}: \mathrm{l}$, Video print of digitally captured image of the $\mathrm{OHC}$ induced to elongate by stepping cell membrane potential from -69 to $-165 \mathrm{mV}$. 2, After return to holding potential of $-69 \mathrm{mV}$. 3 . During voltage step to $+43 \mathrm{mV} .4$. After return to holding potential of -69 mV. 5, Digital subtraction of 3 and 4 indicating distance moved of cuticular plate. Note the obvious shortening of cell during depolarization but the difficulty in observing elongation due to hyperpolarization. Height of black mark in upper-right corner is $6 \mu \mathrm{m}$. B. Mechanical response measured with optoresistors indicating mechanical rectification as cell is stepped for $200 \mathrm{msec}$ to various potentials from the holding potential of $-69 \mathrm{mV}$. the cell's normal resting potential it is capable of shortening to a greater extent than lengthening. Evans (1988) reported that mechanical responses are asymmetrical but that elongation is greater than shortening for a given stimulus strength. In that study, cells were stimulated with transmembrane current via an extracellular electrode, and membrane potential was not measured. Because isolated OHCs can have depolarized membrane potentials, and cell movement is not dependent upon absolute transmembrane current (Santos-Sacchi and Dilger, 1988a, b), it is difficult to interpret these data. It is possible, however, that the results represent responses under depolarized conditions, where hyperpolarization would be a more effective stimulus because of the mechanical response saturation in the depolarizing direction.'

Ashmore (1987) reported on mechanical responses of OHCs under whole-cell voltage clamp. Near the holding potentials

\footnotetext{
' Recently, Evans et al. (1989) have demonstrated that asymmetry in the OHC mechanical response due to extracellular AC current stimulation is biphasic. At low current magnitudes, the "DC" component of the response is toward contraction. However, as the current magnitude is increased, the "DC" component eventually changes towards elongation.
}

used in that study, the mechanical responses were fairly symmetrical but saturated at reported voltage levels far removed from the holding potential (see figure 7, Ashmore, 1987). The rate of saturation in the hyperpolarizing direction was much less than reported here. However, in his study, the estimation of absolute voltage levels was confounded by the very high series resistance of the patch electrodes. The average value of the series resistance can be determined from the data presented in that report and calculates to about $83 \mathrm{M} \Omega .^{2}$ The voltage divider effect

\footnotetext{
'Ashmore (1987) reported that the average time constant of his clamp ( $\left.\tau_{\text {camp }}\right)$ was $1.29 \mathrm{msec}$, which, incidentally, was erroncously reported to be the OHC's membrane time constant. Cell capacitance $(C)$ was reported to be $27.3 \mathrm{pF}$, and from his data on 7 cells that the $\mathrm{OHC}$ mechanical movements were $2.11 \mathrm{~nm} / \mathrm{pA}$. or correspondingly, $19.8 \mathrm{~nm} / \mathrm{mV}$ (p. 331 ), an average input resistance $\left(R_{m}\right)$ of 106 $\mathrm{M} \Omega$ can be deduced. Although this value of input resistance is very similar to our results (Santos-Sacchi and Dilger, 1988a, b), the actual value in his report may be less since series resistance compensation, when performed, was not complete (as indicated in his figure legends). Using this value, however, the average series resistance can be calculated as
}

$$
R_{\mathrm{s}}=\frac{R_{m, \tau_{\text {ciamp }}}}{\left(R_{m,} C_{m}\right)-\tau_{\text {ciamp }}}=83.4 \mathrm{M} \Omega
$$


A

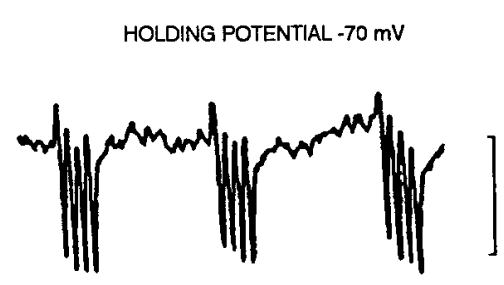

B

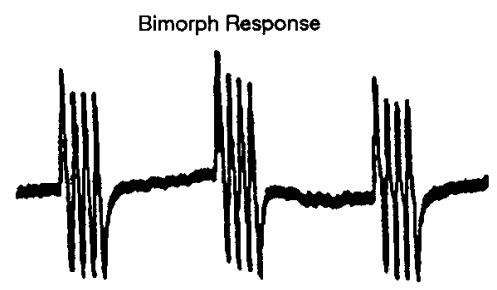

$\mathbf{C}$

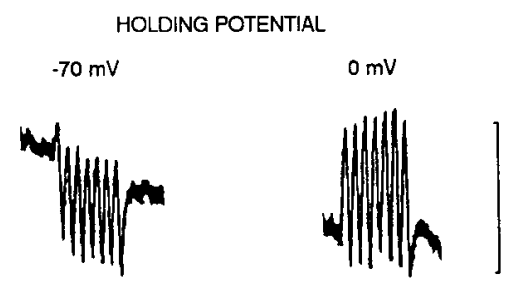

Figure 5. A, This trace depicts the movement of an $\mathrm{OHC}$ in response to $400 \mathrm{msec}$ bursts of a $10 \mathrm{~Hz}$ voltage sinusoid at a level of $90 \mathrm{mV}$ peak to peak. Downward deflections represent cell contractions. Note, in addition to an "AC" displacement at the stimulus frequency, a "DC" shift, indicating a sustained reduction in length during the stimulus. The frequency response of the optoresistor is considerably low-pass, such that the scale for the "AC" component whose magnitude was measured off the video monitor is $0.7 \mu \mathrm{m}$ and that estimated for the "DC" component is about $0.23 \mu \mathrm{m}$. $B$, This trace illustrates the symmetrical response from a bimorph probe at $10 \mathrm{~Hz}$, indicating that the "DC" offset is not due to the measuring procedure. $C$, Both traces illustrate movements of a different cell in response to stimuli as in $A$, except at bursts of $700 \mathrm{msec}$, and at the holding potentials indicated. Note that at the holding potential of $-70 \mathrm{mV}$ the "DC" displacement is in the downward direction (contraction), but at the holding potential of $0 \mathrm{mV}$ the "DC" displacement is in the upward direction (elongation). Scale values are as in $A$.

of such a high series resistance will drastically compromise the amplificr's ability to clamp the potential of OHCs whose membrane resistances are of the same magnitude. Even if series resistance is compensated somewhat, large overestimates of the membrane voltage will exist unless voltages are subsequently corrected for residual series resistance effects, which was not performed in that study. In the present study, patch electrode resistance was initially low and series resistance was corrected for during analysis. A correction for series resistance in Ashmore's data would tend to reconcile some of the differences between our data.

We have previously studied the mechanical responses of $\mathrm{OHCs}$ in response to depolarizing voltage steps and determined that responses as large as $29 \mathrm{~nm} / \mathrm{mV}$ occur (Santos-Sacchi and Dilger, $1988 \mathrm{a}, \mathrm{b})$. In the present study, the average response in the depolarizing direction was about $15 \mathrm{~nm} / \mathrm{mV}$. Ashmore (1987) obtained similar response magnitudes $(19.8 \mathrm{~nm} / \mathrm{mV})$ in the lin-
A

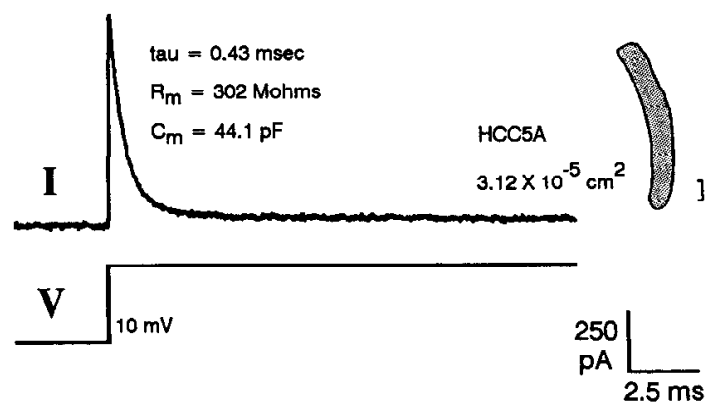

B

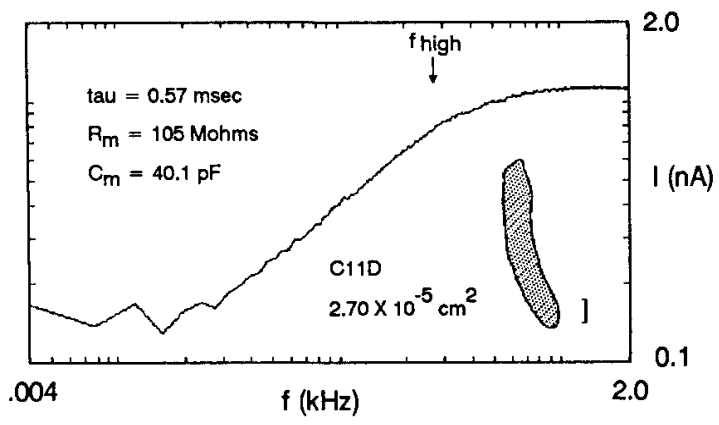

Figure 6. Examples of capacitance determination utilizing transient and $\mathrm{AC}$ analyses. $A, \mathrm{OHC}$ was voltage-clamped at a holding potential near $-70 \mathrm{mV}$ and a voltage step of $10 \mathrm{mV}$ elicited a current response that was analyzed to determine the values indicated. See Materials and Methods for details. Cell outline is shown as drawn from the video monitor. Surface area was estimated as in Materials and Methods. Small scale bar, $10 \mu \mathrm{m} . B$, OHC was voltage-clamped at a holding potential near $-70 \mathrm{mV}$ and the response to a periodic swept frequency burst $(20$ $\mathrm{mV}$ peak) was time-averaged 20 times. The FFT of this average is shown and was used to determine the values indicated. The high-frequency cutoff $\left(f_{\text {high }}\right)$ is $286 \mathrm{~Hz}$. See Materials and Methods for details. Cell outline is shown as drawn from the video monitor. Surfacc arca was cstimated as in Materials and Methods. Small scale bar, $10 \mu \mathrm{m}$.

ear portion of $\mathrm{OHC}$ mechanical responses. The findings of the present study, however, indicate that at the normal resting potential of OHCs in vivo ( -70 to $-90 \mathrm{mV}$; Dallos et al., 1982), mechanical responses are about an order of magnitude smaller, near $2 \mathrm{~nm} / \mathrm{mV}$. Thus, at low sound pressures, where receptor potentials are small and symmetrical, mechanical responses will be small and symmetrical.

Receptor potentials from $\mathrm{OHCs}$ in the apical and basal regions of the cochlea have been recorded in vivo, and the tuning of these cells is as fine as basilar membrane or neural tuning (Dallos et al., 1982; Khanna and Leonard, 1982; Patuzzi and Sellick, 1983; Robles et al., 1986; Russell et al., 1986). Clearly, if basilar membranc tuning is dependent upon an "active" mechanism (Neely and Kim, 1986) and the active mechanism is indeed the mechanical response of $\mathrm{OHCs}$, then the effect should be present at threshold, near sound pressure levels of $0 \mathrm{~dB}$, where the sharpest tuning occurs. At present, the data, especially for the high-frequency region of the organ, are not persuasive. The problem stems from the observation that the mechanical responses of the OHCs are voltage dependent. This dependency places constraints upon the physiological relevance of the phe- 
nomenon at frequencies where hair cell receptor potentials, the presumed stimuli for $\mathrm{OHC}$ mechanical responses, are attenuated by the membrane time constant, $\tau_{\text {cell }}$. The scenario is somewhat more complex; since the mechanical response is dependent upon transmembrane potential, the effects of extracellular potentials, the cochlear microphonic and summating potential, must be accounted for in determining actual transmembrane potential.

The specific capacitance of the $\mathrm{OHC}$ membrane was calculated in the present study to be about $1.2 \mu \mathrm{F} / \mathrm{cm}^{2}$. For the large low-frequency $\mathrm{OHCs}(60-80 \mu \mathrm{m}$ in length) utilized in this study, the calculated membrane time constant, $\tau_{\text {cell }}$, was about $3.5 \mathrm{msec}$. Calculations using data in Ashmore (1987) give a time constant of about $3 \mathrm{msec}$. These figures indicate a cutoff frequency for $\mathrm{OHCs}$ in the low-frequency area of the cochlea of about $46 \mathrm{~Hz}$. This is markedly different from the time constants obtained in vivo from receptor potential measures, where corner frequencies near $1200 \mathrm{~Hz}$ are obtained from OHCs (Dallos and SantosSacchi, 1983). These measures indicate a time constant of 0.13 msec. Of course, input resistance measures of $\mathrm{OHCs}$ in vivo are low, averaging $30 \mathrm{M} \Omega$ or less. This may be due to the poor sealing properties of the high-resistance microelectrodes used and may account for the small time constants observed. Alternatively, the input resistance of hair cells under in vivo conditions may be less than measured in vitro. Ohmori (1985) obtained time constants for vestibular hair cells in vitro that ranged from 4.5 to $50 \mathrm{msec}$. He speculated that activation of membrane conductances at physiologically depolarized membrane potentials may reduce the cell's time constant. For OHCs in the highfrequency region of the cochlea where cell length is about onethird, the time constant should not be too different from that of the low-frequency $\mathrm{OHC}$, considering that, as capacitance of the cell decreases due to less membrane surface area, input resistance will likely increase.

Response magnitudes near auditory threshold for OHCs in the apical and basal regions are quite small. Electrical measurements made in the low-frequency area of the cochlea are not hampered by the roll-off associated with high-impedance electrode filter characteristics, but in the high-frequency region corrections are required. After such corrections (Russell et al., 1986), threshold measures from OHCs in the $14 \mathrm{kHz}$ region indicate $\mathrm{AC}$ responses near $15 \mu \mathrm{V}$. In the $0.8 \mathrm{kHz}$ region, $\mathrm{AC}$ responses in OHCs at $0 \mathrm{~dB}$ SPL have been measured, and magnitudes up to $100 \mu \mathrm{V}$ occur (Dallos and Santos-Sacchi, 1983; Dallos, personal communication). Using this information from low-frequency $\mathrm{OHCs}$, a corroboration of the $\mathrm{OHC}$ response at $14 \mathrm{kHz}$ can be made, considering a $6 \mathrm{~dB} /$ octave roll-off above $1200 \mathrm{~Hz}$ for in vivo OHCs (Dallos and Santos-Sacchi, 1983; Russell et al., 1986). The calculated value of about $9 \mu \mathrm{V}$ is in agreement with that calculated from Russell et al. (1986). Thus, estimates of $\mathrm{OHC}$ mechanical responses (assuming a $2 \mathrm{~nm} / \mathrm{mV}$ movement at resting potentials near $-70 \mathrm{mV}^{3}$ ) generated by

\footnotetext{
${ }^{3}$ The symmetrical AC receptor potentials noted in high-frequency OHCs (Russcll ct al., 1986) may lead some to infer that these OHCs function in the linear region of their $I-V$ function and hence to infer that these cells normally function in the linear $(15-29 \mathrm{~nm} / \mathrm{mV})$ range of the voltage-cell displacement function described here. The $I-V$ functions described for $\mathrm{OHCs}$ by various investigators are essentially DC evaluations and therefore cannot be used to predict highfrequency response characteristics. The current traces depicted here (Figs. 1, 2) and in previous reports (Santos-Sacchi and Dilger, 1988a, b) clearly show that the outward rectification is time dependent, with a time constant of several milliseconds. At increasingly smaller time intervals following voltage stimulation, the traces clearly show that the $I-V$ response becomes more and more linear, and more accurately reflects basolateral conductance effects upon high-frequency receptor potentials. Clearly, the $\mathrm{OHC}$ can produce symmetrical AC receptor poten-
}

receptor potentials near threshold are probably less than 0.03 $\mathrm{nm}$ in magnitude. Corresponding basilar membrane displacement at the high-frequency region is $0.35 \mathrm{~nm}$ (Sellick et al., 1982), which indicates a disparity of about $21 \mathrm{~dB}$ between basilar membrane displacement and $\mathrm{OHC}$ movements.

These calculations indicate that a possible influence of $\mathrm{OHC}$ mechanical responses at threshold is questionable, especially at high frequencies where active mechanisms are most expected. At higher suprathreshold levels, however, 2 mechanisms will affect the mechanical movements of the OHCs-first, the inherent nonlinear mechanical response magnitude function described here (i.e., a shift from $2 \mathrm{~nm} / \mathrm{nV}$ towards $15 \mathrm{~nm} / \mathrm{mV}$ at increasing depolarization levels) and, second, the inherent rectification present in the receptor potential generator mechanism (Dallos et al., 1982; Russell et al., 1986). Theoretically, these 2 mechanisms should jointly promote an increased OHC shortening at progressively higher sound pressure levels, thereby raising the likelihood of OHC-basilar membrane interactions. In fact, at suprathreshold levels, rectified mechanical responses of OHCs may underlie some of the rapid "DC" basilar membrane displacements noted by LePage (1987) in response to tone bursts of 55-75 dB SPL. On the other hand, the cumulative displacements he also noted are not likely to reflect the fast mechanical motion of the OHCs but conceivably may be due to osmoticor $\mathrm{K}^{+}$-induced $\mathrm{OHC}$ morphologic alterations (Zenner et al., 1985), which have a longer time course than the electrically induced movements. In vivo the time course of these slower movements may further reflect an ability of electrically communicating supporting cells to buffer $\mathrm{K}^{+}$released into the spaces of Nuel during hair and nerve cell excitation (Santos-Sacchi, 1986).

The demonstration by Kemp (1978) of otoacoustic emissions initiated the growing consensus that passive basilar membrane tuning is fine-tuned by an "active process" that somehow involves the OHC. A body of data confirms the OHC's role (Mountain, 1980; Siegal and Kim, 1982; Brown et al., 1983; Nuttall, 1985); and with the discovery of Brownell (1983), the source of this "active process" was assumed to be the ability of the OHC to alter its length (Geisler, 1986). The voltage dependence of these OHC mechanical responses (Santos-Sacchi and Dilger, 1988a, b) and the results presented here place constraints upon this assumption and suggest that other mechanisms may be involved. Indeed, it may be that a variety of factors supplementary to $\mathrm{OHC}$ mechanical responses, such as stereociliar and tectorial membrane micromechanics (Allen, 1980, 1988; Zwislocki and Kletsky, 1980; Crawford and Fettiplace, 1985; Zwislocki, 1986; Howard and Hudspeth, 1987) mutually effect sharp tuning at auditory threshold.

\section{References}

Allen, J. B. (1980) Cochlear micromechanics-A physical model of transduction. J. Acoust. Soc. Am. 68: 1660-1670.

Allen, J. B. (1988) Cochlear signal processing. In Physiology of the Ear, A. F. Jahn and J. Santos-Sacchi, eds., pp. 243-270, Raven, New York.

tials at resting potentials ranging from -70 to $-100 \mathrm{mV}$, if rectifying basolateral conductances are not activated by these potentials either because of their speed or small amplitude. Thus, symmetrical AC receptor potentials do not require that the cell function in the linear portion of the $I-V$ curve, and likewise do not indicate that the $\mathrm{OHC}$ is functioning in the $15-29 \mathrm{~nm} / \mathrm{mV}$ range of the voltage-cell displacement function. The important factor determining whether the cell functions in the 2 or the $15-29 \mathrm{~nm} / \mathrm{mV}$ range is the resting potential. OHCs whose normal resting potential is from -70 to $-100 \mathrm{mV}$ should function in the $2 \mathrm{~nm} / \mathrm{mV}$ range, unless the cell is sufficiently depolarized. 
Ashmore, J. F. (1986) The cellular physiology of isolated outer hair cells: Implications for cochlear frequency selectivity. In Auditory Frequency Selectivity, B. C. J. Moore and R. D. Patterson, eds., pp. 103108, Plenum, New York.

Ashmore, J. F. (1987) A fast motile response in guinea-pig outer hair cells: The cellular basis of the cochlear amplifier. J. Physiol. (Lond.) 388: 323-347.

Ashmore, J. F., and W. E. Brownell (1986) Kilohertz movements induced by electrical stimulation in outer hair cells isolated from the guinea-pig cochlea. J. Physiol. (Lond.) 377: 41P.

Brown, M. C., A. L. Nuttall, and R. I. Masta (1983) Intracellular recordings from cochlear inner hair cells: Effects of stimulation of the crossed olivocochlear efferents. Science 222: 69-72.

Brownell, W. E. (1983) Observations on a motile response in isolated outer hair cells. In Mechanisms of Hearing. W. R. Webster and L. M. Aitken, eds., pp. 5-10, Monash University Press, Clayton, Australia.

Brownell, W. E. (1984) Microscopic observation of cochlear hair cell motility. Scanning Electron Microsc. 1984/III: 1401-1406.

Brownell, W. E. (1986) Outer hair cell motility and cochlear frequency selectivity. In Auditory Frequency Selectivity, B. C. J. Moore and R. D. Patterson, cds., pp. 109-1 16, Plenum, New York.

Brownell, W. E., C. R. Bader, D. Bertrand, and Y. de Ribaupierre (1985) Evoked mechanical responses of isolated cochlear outer hair cells. Science 227: 194-196.

Crawford, A. C., and R. Fettiplace (1985) The mechanical propertics of ciliary bundles of turtle cochlear hair cells. J. Physiol. (Lond.) 364: 359-379.

Dallos, P. (1983) Some electrical circuit properties of the organ of Corti. I. Analysis without rcactive elements. Hear. Res. 12: 89-119.

Dallos, P., and J. Santos-Sacchi (1983) AC receptor potentials from hair cells in the low frequency region of the guinea pig cochlea. In Mechanisms of Hearing, W. R. Webster and L. M. Aitken, eds., pp. 11-16, Monash University Press, Clayton, Australia.

Dallos, P., J. Santos-Sacchi, and A. Flock (1982) Intracellular recordings from cochlear outer hair cells. Science 218: 582-584.

Evans, B. (1988) Asymmetries in outer hair cell clectro-mechanical responses. In Association for Research in Otolaryngology Abstracts of the Eleventh Midwinter Research Meeting, p. 29, Clearwater Beach, FL.

Evans, B., P. Dallos, and R. Hallworth (1989) Asymmetries in motile responses of outer hair cells in simulated in vivo conditions. In $\mathrm{Me}$ chanics of Hearing. J. P. Wilson and D. T. Kemp, eds. (in press).

Geisler, C. D. (1986) A model of the effect of outer hair cell motility on cochlear vibrations. Hear. Res. 24: 125-131.

Howard, J., and A. J. Hudspeth (1987) Mechanical relaxation of hair bundle mediates adaptation in mechanoelectrical transduction by the bullfrog's saccular hair cell. Neuron $1:$ 189-199.

Kachar, B., W. E. Brownell, R. Altschuler, and J. Fex (1986) Electrokinetic shape changes of cochlear outcr hair cells. Nature 322: 365368.

Kemp, D. T. (1978) Stimulated acoustic emissions from within the human auditory system. J. Acoust. Soc. Am. 64: 1386-1391.

Khanna, S. M., and D. G. B. Leonard (1982) Basilar membrane tuning in the cat cochlea. Science 215: 305-306.

Lakshminarayanaiah, N. (1984) Equations of Membrane Biophysics, Academic, Orlando, FL.

Lecar. H., and T. G. Smith. Jr. (1985) Voltage clamping small cells In Voltage and Patch Clamping with Microelectrodes, T. G. Smith, Jr., H. Lecar, S. J. Redman, and P. W. Cage, eds., pp. 231-256, American Physiological Society, Bethesda, MD.

LePage, E. L. (1987) Frequency-dependent self-induced bias of the basilar membrane and its potential for controlling sensitivity and tuning in the mammalian cochlea. J. Acoust. Soc. Am. 82: 139-154.

Marty, A., and E. Neher (1983) Tight-seal whole-cell recording. In Single-Channel Recording, B. Sakmann and E. Neher, eds., pp. 107122, Plenum, New York.
Mountain, D. C. (1980) Changes in endolymphatic potential and crossed olivocochlear bundle stimulations alter cochlear mechanics. Science 210: $71-72$.

Necly, S. T., and D. O. Kim (1986) A model for active elements in cochlear biomechanics. J. Acoust. Soc. Am. 79: 1472-1480.

Nuttall, A. L. (1985) Influence of direct current on dc receptor potentials from the cochlear inner hair cells in the guinea pig. J. Acoust. Soc. Am. 77: 165-175.

Ogden, D. C., and P. R. Stanfield (1987) Introduction to single channel recording. In Microelectrode Techniques: The Plymouth Workshop Handbook, N. B. Standen, P. T. A. Gray, and M. J. Whitaker, eds., pp. 63-81, The Company of Biologists, Ltd., Cambridge, U.K.

Ohmori, H. (1984) Studies of ionic currents in the isolated vestibular hair cell of the chick. J. Physiol. (Lond.) 350: 561-581.

Ohmori, H. (1985) Mechano-electrical transduction currents in isolated vestibular hair cells of the chick. J. Physiol. (Lond.) 359: 189217.

Patuzzi, R. B., and P. Sellick (1983) A comparison between basilar membranc and inner hair cell receptor potential input-output functions in the guinea pig cochlea. J. Acoust. Soc. Am. 74: 1731-1741.

Robles, L., M. A. Ruggero, and N. C. Rich (1986) Basilar membrane mechanics at the base of the chinchilla cochlea. I. Input-output functions, tuning curves, and response phases. J. Acoust. Soc. Am. 80: $1364-1374$.

Russell, I. J., and P. M. Sellick (1983) Low frequency characteristics of intracellularly recorded receptor potentials in mammalian hair cells. J. Physiol. (Lond.) 338: 179-206.

Russell, I. J., A. R. Cody, and G. P. Richardson (1986) The responses of inner and outer hair cells in the basal turn of the guinea-pig cochlea and in the mouse cochlea grown in vitro. Hear. Res. 22: 199-216.

Santos-Sacchi, J. (1986) Dye coupling in the organ of Corti. Cell Tissue Res. 245: 525-529.

Santos-Sacchi, J. (1988a) Whole cell voltage clamp studies on isolated outer hair cells. Current Concepts of Hair Cell Function: A Consensus Meeting. Kresge Hearing Research Institute, University of Michigan, June 1988, Ann Arbor, MI

Santos-Sacchi, J. (1988b) Rectified mechanical responses in outer hair cells from the mammalian organ of Corti. In Abstracts Fourth International Congress of Cell Biology, p. 155, Montreal, Qućbec, Canada.

Santos-Sacchi, J., and J. P. Dilger (1986) Patch clamp studies on isolated outer hair cells. In Advances in Auditory Neuroscience, p. 23, The IUPS Satellite Symposium on Hearing, University of California, San Francisco. CA.

Santos-Sacchi, J., and J. P. Dilger (1988a) Whole cell currents and mechanical responses in outer hair cells. In Association for Research in Otolaryngology . Abstracts of the Eleventh Midwinter Meeting. $\mathrm{p}$. 171, Clearwater Beach, FL.

Santos-Sacchi, J., and J. P. Dilger (1988b) Whole cell currents and mechanical responses of isolated outer hair cells. Hear. Res. 35: 143150.

Sellick, P. M., R. Paturzi, and B. M. Johnstone (1982) Measurement of basilar membrane motion in the guinea pig using the Mossbauer technique. J. Acoust. Soc. Am. 72: 131-141.

Siegal, J. H., and D. O. Kim (1982) Efferent neural control of cochlear mechanics? Olivocochlear bundle stimulation affects cochlear biomechanical nonlinearity. Hear. Res. 6: 171-182.

Spoendlin. H. (1969) Innervation patterns in the organ of Corti of the cat. Acta Otolaryngol. (Stockh.) 67: 239-254.

Zenner, H. P., U. Zimmermann, and U. Schmitt (1985) Reversible contraction of isolated mammalian cochlear hair cells. Hear. Res. 18: 127-133.

Zwislocki, J. J. (1986) Analysis of cochlear mechanics. Hear. Res. 22: 155-169.

Zwislocki, J. J., and E. J. Kletsky (1980) Micromechanics in the theory of cochlear mechanics. Hear. Res. 2: 505-512. 